\title{
STUDI KESANTUNAN TINDAK TUTUR ASERTIF DI KALANGAN PEGAWAI DI KABUPATEN BIMA DALAM PELAYANAN PRIMA (KAJIAN SOSIOPRAGMATIK)
}

\author{
${ }^{1}$ Nurmiwati, ${ }^{2}$ Linda Ayu Darmurtika \\ Dosen Program Studi Pendidikan Bahasa dan Sastra Indonesia \\ FKIP Universitas Muhammadiyh Mataram
}

\begin{abstract}
Abstrak
Tujuan penelitian ini adalah: 1) mendeskripsikan dan menjelaskan fungsi tindak tutur asertif di kalangan pegawai pemerintah yang berada di lingkungan kantor daerah kabupaten Bima dalam pelayanan prima. 2) mendeskripsikan dan menjelaskan strategi kesantunan tindak tutur asertif pegawai pemerintah dilingkungan kantor daerah kabupaten Bima dalam pelayanan prima. luaran yang ingin dicapai yaitu; 1) hasil penelitian ini nantinya dapat memperkaya khazanah ilmu pengetahuan di bidang linguistik khususnya ilmu sosiopragmatik tentang teori tindak tutur yang dikaitkan dengan kesantunan terutama sekali dalam pelayanan prima. Di samping itu, hasil penelitian ini diharapkan dapat memberi referensi tentang tindak tutur secara asertif dalam pelayanan prima oleh pegawai pemerintah sebagai pelayan masyarakat. 2) hasil penelitian ini dapat dibuat buku pedoman bagi lembaga-lembaga pemerintah dalam memberikan pelayanan kepada masyarakat publik terutama dalam penerapan stategi pelayanan prima. Adapun metode yang digunakan untuk penganalisisas data adalah deskriptif kualitatif. Data dikumpulkan dengan melakukan observasi, merekam dan mencatat dan mengumpulkan data dalam dokumentasi. Langkah-langkah analisis data yakni reduksi, penyederhanaan, penyajian, deskripsi dan penarikan simpulan. Data yang diperoleh dari hasil observasi. Data yang paling pokok dalam penelitian ini yang berkaitan dengan tindak tutur asertif yang dilakukan oleh pegawai pemeritah di lingkungan kantor daerah kabupaten Bima. Adapun hasil penelitian ini menunjukkan adanya penggunaan tindak tutur secara asertif dalam melakukan kegiatan tindak tutur dengan mitra tuturnya dalam menyatakan, memberitahukan, menyarankan, membanggakan, mengeluh, menuntut, dan melaporkan. Dan srategi yang digunakan dalam melakukan tindak tutur secara asertif yaitu strategi positif dan negatif.
\end{abstract}

Kata Kunci : Tindak tutur Asertif dalam Pelayanan Prima

\section{PENGANTAR}

Kesantunan berbahasa merupakan bagian penting dalam melakukan pelayanan prima. Standar pelayanan merupakan ukuran yang telah ditentukan sebagai suatu pembakuan pelayanan yang baik. Standar pelayanan mengandung baku mutu pelayanan. Pengertian mutu menurut Goetsch dan Davis merupakan kondisi dinamis yang berhubungan dengan produk, jasa, manusia, proses dan lingkungan yang memenuhi atau melebihi harapan pihak yang menginginkannya. Dalam teori pelayanan publik, tolak ukur yang dipergunakan sebagai pedoman penyelenggaraan pelayanan dan acuan penilaian kualitas pelayanan sebagai komitmen atau janji dari penyelenggara 
negara kepada masyarakat untuk memberikan pelayanan yang berkualitas kepada masyarakat seharusnya pelayanan publik yang diberikan (pelayanan prima) oleh birokrasi pemerintah mengacu pada aturan baku pemerintah sebagaimana dirumuskan dalam kebijakan strategis melalui Keputusan Menteri Pendayagunaan Aparatur Negara (PAN) Nomor 63/Kep/M.PAN/7/2003 (Menpan, 2003:2) tentang Pedoman Umum Penyelenggaraaan Pelayanan Publik yang meliputi Kesederhanaan, Kejelasan, Akurasi, Keamanan, Tanggung Jawab, Kelengkapan Sarana dan Prasarana, Kedisiplinan, Kesopanan dan Keramahan.

Kesopanan dan keramahan dalam memberikan pelayan merupakan bagian penting dalam pelayanan prima yang diberikan oleh pemerintah sebagai pelayan masyarakat. Pemberian pelayanan harus mengedepankan kesopanan dan keramahan. Kesopanan dan keramahan seorang pelayan masyarakat dapat ditunjukan dengan penggunaan tindak tuturnya, terutama sekali pilihan kata yang digunakan dalam memberikan pelayanan.

Di sektor publik ada tiga fungsi pelayanan yang dilakukan pemerintah, yakni: environmental service, development service, dan protective service. Pelayanan oleh pemerintah dibedakan berdasarkan siapa yang menerima layanan tersebut, apakah pihak individu atau pihak kelompok. Kemudian konsep barang layanan terdiri dari barang privat (private goods) dan barang layanan kolektif (public goods). Dengan adanya aturan yang dibuat sebagai standar dalam melakukan pelayanan kepada masyarakat yang dilakukan oleh pemerintah pusat dalam hal ini Keputusan Menteri Pendayagunaan Aparatur Negara (PAN) Nomor 63/Kep/M.PAN/7/2003 (Menpan, 2003:2) tentang Pedoman Umum Penyelenggaraaan Pelayanan Publik yang meliputi Kesederhanaan, Kejelasan, Akurasi, Keamanan, Tanggung Jawab, Kelengkapan Sarana dan Prasarana, Kedisiplinan, Kesopanan dan Keramahan. Apakah aturan tersebut dapat dilaksanakan dengan baik oleh pegawai pemerintah yang ada ditingkatan daerah khususnya oleh pegawai pemerintah yang ada dikabupaten Bima sebagai bagian dari abdi Negara yang menjadi pelayan bagi masyarakat.

Penjelasan di atas mengarahkan tentang pelayanan yang baik juga memandang kesopanan dan keramahan merupakan bagian penting yang harus diperhatikan, dalam hal ini peneliti memandang bahwa kesantunan tindak tutur secara asertif yang berkaitan dengan tindak tutur yang mengikat penuturnya tentang kebenaran atas apa yang dikatakan (misal: menyatakan, melaporkan, mengabarkan, 
menunjukan, menyebutkan). Tentang informasi yang disampaikan kepada mitra tutur harus didasarkan pada kebenaran dari informasi tersebut sehingga pelayanan prima terwujud dalam tindak kesantunan secara asertif.

\section{LANDASAN TEORI}

Teori yang dijadikan landasan dalam penelitian ini yaitu teorinya Austin (1986) tentang tindak tutur dan dan jenis tindakan dalam melkukan tindak tutur yaitu teorinya Tarigan (2007:42) menjelaskan klasifikasi tindak ilokusi berdasarkan berbagai fungsi individu dengan mengutip penjelasan seorang pakar kawakan dalam bidang ini, J.R. Searle (1979), mengklasifikasikan tindak ilokusi berdasarkan berbagai fungsi individu sebagai berikut.

1) Asertif: melibatkan pembicara pada kebenaran proposisi yang diekspresikan, misalnya: menyatakan, memberitahukan, menyarankan, membanggakan, mengeluh, menuntut, dan melaporkan. Ilokusi-ilokusi yang seperti ini cenderung bersifat netral dari segi kesopansantunan, dengan demikian dapat dimasukkan ke dalam kategori kolaboratif, misalnya membanggakan, menyombongkan yang pada umumnya dianggap tidak sopan secara semantic, asertif bersifat proposisional.
2) Direktif: dimaksudkan untuk menimbulkan beberapa efek melalui tindakan sang penyimak, misalnya: memesan, memerintahkan, memohon, meminta, menyarankan, menganjurkan, dan menasihatkan. Semua ini seringkali termasuk ke dalam kategori kompetitif, dan terdiri atas suatu kategori ilokusi-ilokusi di mana kesopansantunan yang negatif menjadi penting. Sebaliknya, beberapa direktif (seperti undangan) pada hakikatnya dianggap sopan. Perlu dicatat bahwa untuk menghilangkan kebingungan dalam pemakaian istilah direktif dalam hubungannya dengan 'direct and indirect illocutions', Leech menganjurkan pemakaian istilah impositif bagi ilokusi-ilokusi kompeteitif dalam kelas ini.

3) Komisif: melibatkan pembicara pada beberapa tindakan yang akan datang, misalnya: menjanjikan, bersumpah, menawarkan, dan memanjatkan (doa). Semua ini cenderung bersifat konvivial daripada kompetitif, dilaksanakan justru lebih memenuhi minat seseorang daripada sang pembicara.

4) Ekspresif: mempunyai fungsi untuk mengekspresikan, mengungkapkan atau memberitahukan sikap psikologis sang pembicara menuju suatu pernyataan keadaan yang diperkirakan 
oleh ilokusi. Misalnya: mengucapkan terima kasih, mengucapkan selamat, memaafkan, mengampuni, menyalahkan, memuji, menyatakan belasungkawa, dan sebagainya. Seperti juga halnya komisif, maka semua ini juga cenderung menjadi konvivial, dan oleh sebab itu pada hakikatnya dianggap sopan. Akan tetapi sebaliknya juga dapat dibenarkan, misalnya ekspresif-ekspresif seperti 'menyalahkan' dan 'menuduh'.

5) Deklaratif: adalah ilokusi yang 'bila performansinya berhasil' akan menyebabkan korenpondensi yang baik antara isi proposisional dengan realitas. Contoh: menyerahkan diri, memecat, membebaskan, membaptis, memberi nama, menamai, mengucilkan, mengangkat, menunjuk, menentukan, menjatuhkan hukuman, menvonis, dan sebagainya. Semua yang tersebut di sini merupakan kategori tindak ujar yang khas; semua itu dilakukan oleh seseorang yang mempunyai wewenang khusus dalam lembaga tertentu.

\section{Strategi Penyampaian Tindak Tutur}

Setiap komunikasi antara individu pasti saling menyampaikan informasi yang berupa pikira, gagasan, perasaan maupun emosi secara langsung dan tidak langsung. Penyampain informasi berupa pikiran, gagasan, perasaan maupun emosi tentu harus dipikirkan bagaimana starategi penyampainnya. Strategi tindak tutur adalah cara-cara yang digunakan partisipan tutur dalam mengekspresikan tindak atau fungsi tindak tutur menggunakan tuturan tertentu. Dalam kaitan ini, Wijana (1996:4) dapat dibedakan menjadi tindak tutur langsung dan tindak tutur tidak langsung. Wijana mengisyaratkan bahwa strategi penyampaian tindak atau fungsi tindak tutur dapat diwujudkan dengan tuturan bermodus deklaratif, interogatif, dan imperatif (bermakna literal atau nonliteral dan langsung atau tidak langsung).

Strategi penyampain tindak tutur yang dilakukan antara penutur dan lawan tuturnya menuntun keduanya pada arah penggunaan bentuk dan isi sebagai pilihan dalam melakukan tindak tutur. bentuk berkaitan dengan bagaimana suatu tuturan diformulasikan atau bagaimana ciri formal (berupa pilihan bahasa dan variasi linguistik) suatu tuturan dipakai untuk mewujudkan suatu ilokusi. Dimensi isi berkaitan maksud yang terkandung pada tuturan tersebut. Starategi dalam penyampain isi tuturan juga akan mempengaruhi makna yang akan ditangkap oleh mitra tutur.

\section{Kesantunan}

Kesantunan dalam berbahasa mungkin merupakan horison baru dalam berbahasa, dan sampai saat ini belum 
dikaji dalam konstelasi linguistik; terkecuali dalam telaah pragmatik. Kesantunan dalam berbahasa, meskipun disebut sebagai horison baru, namun sudah mendapatkan perhatian oleh banyak linguis dan pragmatisis. Sebagai bidang baru dalam kajian kebahasaan, khususnya bahasa dalam penggunaan (language in use), kesantunan (politeness) dalam berbahasa seyogiyanya mendapatkan perhatian, baik oleh pakar atau linguis, maupun para pembelajar bahasa. Selain itu, penting juga bagi setiap orang untuk memahami kesantunan berbahasa ini, karena manusia yang kodratnya adalah "makhluk berbahasa" senantiasa melakukan komunikasi verbal yang sudah sepatutnya beretika.

\section{Teori Kesantunan}

Sopan santun sering diartikan secara dangkal sebagai suatu 'tindakan yang sekadar beradab (Leech, 1982:161). Kesantunan itu sendiri memiliki makna yang berbeda dengan kesopanan. Kata sopan memiliki arti menunjukkan rasa hormat pada mitra tutur, sedangkan kata santun memiliki arti berbahasa (atau berprilaku) dengan berdasarkan pada jarak sosial antara penutur dan mitra tutur. Menurut Brown dan Levinson (1987), yang mana terinspirasi oleh Goffman (1967), bahwasanya bersikap santun itu adalah bersikap peduli pada "wajah" atau "muka," baik milik penutur, maupun milik mitra tutur. "Wajah," dalam hal, ini bukan dalam arti rupa fisik, namun "wajah" dalam artian public image, atau mungkin padanan kata yang tepat adalah "harga diri" dalam pandangan masyarakat.

Konsep wajah ini berakar dari konsep tradisional di Cina, yang dikembangkan oleh Konfusius terkait dengan nilai-nilai kemanusiaan (Aziz, 2008). Pada wajah, dalam tradisi Cina, melekat atribut sosial yang merupakan harga diri, sebuah penghargaan yang diberikan oleh masyarakat, atau dimiliki secara individu. Wajah, merupakan "pinjaman masyarakat," sebagaimana sebuah gelar akademik yang diberikan oleh sebuah perguruan tinggi, yang kapan saja bisa ditarik oleh yang memberi. Oleh karena itu, si pemilik wajah itu haruslah berhati-hati dalam berprilaku, termasuk dalam berbahasa. Jika Goffman (1967) menyebutkan bahwa wajah adalah atribut sosial, maka Brown dan Levinson (1987) menyebutkan bahwa wajah merupakan atribut pribadi yang dimiliki oleh setiap insan dan bersifat universal. Dalam teori ini, wajah kemudian dipilah menjadi dua jenis: wajah dengan keinginan positif (positive face), dan wajah dengan keinginan negatif (negative face). Wajah positif terkait dengan nilai solidaritas, ketakformalan, pengakuan, dan 
kesekoncoan. Sementara itu, wajah negatif bermuara pada keinginan seseorang untuk tetap mandiri, bebas dari gangguan pihak luar, dan adanya penghormatan pihak luar terhadap kemandiriannya itu (Aziz, 2008:2). Melihat bahwa wajah memiliki nilai seperti yang telah disebutkan, maka nilai-nilai itu patut untuk dijaga, dan salah satu caranya adalah melalui pola berbahasa yang santun, yang tidak merusak nilai-nilai wajah itu.

\section{Kategori kesantunan asertif}

Representatif merupakan tindak tutur yang mengikat penuturnya kepada kebenaran atas hal yang dikatakannya. Tindak tutur jenis ini juga disebut dengan tindak tutur asertif. Yang termasuk tindak tutur jenis ini adalah tuturan menyatakan, menuntut, mengakui, menunjukkan, melaporkan, memberikan kesaksian, menyebutkan, berspekulasi. Contoh jenis tuturan ini adalah: "bapak rektor sedang ada rapat". Tuturan tersebut termasuk tindak tutur representatif sebab berisi informasi yang penuturnya terikat oleh kebenaran isi tuturan tersebut. Penutur bertanggung jawab bahwa tuturan yang diucapkan itu memang fakta dan dapat dibuktikan di lapangan bahwa bapak rektor memang sedang rapat.

\section{Dalam kehidupan sehari-hari} seseorang tidak terlepas dari kegiatan berkomunikasi, tetapi tidak jarang dari berkomunikasi itu justru menyinggung perasaan orang lain bahkan banyak terjadi perselisihan diantara mereka dikarenakan kesalahan-kesalahan persepsi yang diterimanya karena dilecehkan dan lain sebagainya (berperilaku agresif), dan dengan berperilaku asertif maka orang lain dapat mengerti apa yang kita harapkan.

Berpikir asertif adalah kemampuan untuk mengkomunikasikan pikiran, perasaan dan keinginan secara jujur kepada orang lain tanpa merugikan orang lain. Apabila kita mampu mengungkapkan perasaan negatif(marah, jengkel) secara jujur sesuai dengan apa yang kita rasakan tanpa menyalahkan orang lain, maka hal tersebut kita sudah bertindak secara asertif. Bertindak atau berperilaku asertif tidak hanya sebatas untuk mengungkapkan perasaan yang positif (senang) tetapi juga perasaan yang negatif. Orang yang berperilaku asertif memiliki karakteristik. antara lain;1) mampu terbiasa mengekspresikan pikiran dan persaan pada orang lain, 2) meminta pertolongan pada orang lain pada saat membutuhkan pertolongan, 3) sering bertanya pada saat sedang bingung, 4) pada saat berbeda pendapat dengan orang lain, mampu mengungkapkan pendapatnya secara jujur dan terbuka, 5) memandang wajah orang yang diajak berbicara pada saat berbicara dengannya, 6) pada saat tidak ingin 
melakukan suatu pekerjaan, mampu berkata tidak.

\section{Pelayanan Prima}

Tujuan pelayanan prima adalah memberikan pelayanan yang dapat memenuhi dan memuaskan pelanggan atau masyarakat serta memberikan fokus pelayanan kepada pelanggan. Pelayanan prima dalam sektor publik didasarkan pada aksioma bahwa "pelayanan adalah pemberdayaan". Pelayanan pada sektor bisnis berorientasi profit, sedangkan pelayanan prima pada sektor publik bertujuan memenuhi kebutuhan masyarakat secara sangat baik atau terbaik. Pelayanan tindak tutur asertif seseorang dapat menimbulkan dampak seperti; 1) tidak membiarkan orang lain mengambil manfaat dari kondisi yang kita alami, dan orang lain juga memiliki kebebasan untuk mengungkapkan apa yang dirasakan, 2) tidak berperilaku agresif terhadapa orang lain, bahkan menerima kehadiran orang lain dengan sikap terbuka, 3) kedua belah pihak yang berkomunikasi merasa nyaman, tidak ada yang merasa ingin menyakiti lawan bicaranya dan tidak ada yang merasa disakiti hatinya, 4) tidak ada pihak yang merasa disalahkan dan dihina oleh keberadaan emosi negatif yang dirasakan oleh lawan bicaranya, 5) lawan bicara tidak terpancing untuk memberikan respon yang emosional.

\section{METODE PENELITIAN}

Penggunaan metode yang tepat dalam sebuah penelitian dapat memberikan hasil yang maksimal dalam penelitian yang kita lakukan begitu pula peneltian ini. Metode yang digunakan peneliti adalah penelitian kualitatif dengan tujuan untuk memaparkan data sebagaimana adanya. Data yang dikumpulkan diperoleh dengan menggunakan teknik observasi, teknik rekam, teknik catat dan teknik dokumentasi. Data yang terkumpul dianalisis dengan menggunakan metode identifikasi, melakukan klasifikasi dan dilengkapi dengan interpretasi data.

\section{HASIL DAN PEMBAHASAN}

berdasarkan hasil penelitian yang dilaksanakan oleh peneliti tentang tindak tutur secara asertif yang dilakukan oleh pegawai dilingkungan kantor daerah kabupaten Bima yaitu tentang fungsi penggunaan tindak tutur secara asertif dan stategi dalam penyampain tindak tutur secara asertif yang dilakukan oleh para pegawai dilingkungan kantor daerah kabupaten Bima.

1) Fungsi Tindak Tutur Secara Asertif Dikalangan Pegawai di Kantor Daerah Kabupaten Bima dalam Memberikan Pelayanan Prima Pemakaian tindak tutur asertif yang digunakan oleh para pegawai dalam memberikan pelayan kepada 
masyarakat dan atasnya dapat kita jumpai dalam menyatakan, memberitahukan, menyarankan, membanggakan, mengeluh, menuntut, dan melaporkan. Sehingga kesantunan secara asertif yang dipakai ada 7 seperti yang disampaikan sebelumnya.

Adapun kutipan data yang dianalisis berdasarkan hasil temuan dilapangan adalah sebagai berikut.

1. Fungsi tindak tutur secara asertif untuk menyatakan. Tuturan tersebut digunakan untuk menanyakan tentang tujuan dari kedatangan mitra tuturnya ke kantor tersebut. Tindak tutur dalam hal ini juga sebagai bentuk menunjukan keramah tamahan dalam memberikan pelayanan kepada masyarakat yang memiliki kepentingan, sehingga sesegerah mungkin diberikan pelayanan sehingga dapat diketahui tujuan dari kedatang masyarakat tersebut.

2. Fungsi tindak tutur secara aserif untuk memberitahukan. Tuturan tersebut digunakan oleh pegawai untuk menginformasikan kepada masyarakat untuk menunggu atau menuju tempat selanjutnya sebagai tujuan untuk meperlancar pembetahuan informasi yang dibutuhkan oleh masyarakat. mengenai lokasi dari tiap ruangan yang akan dituju atau tentang informasi yang berkaitan dengan orang yang dituju dikantor tersebut.

3. Fungsi tindak tutur secara aserif untuk menyarankan. Tuturan tersebut disampaikan untuk memberikan saran kepada mitra tutur yang diberikan pelayanan agar menunggu apa bila peleyanan dapat diproses saat itu juga atau menyarankan untuk kembali lagi dilain hari apa bila pelayanan tidak dapat diproses pada hari yang sama. Dan juga digunakan untuk memberikan alternatif agar masyarakat tidak merasa kecewa dengan pelayanan yang diberikan.

4. Fungsi tindak tutur secara aserif untuk membanggakan. Tuturan tersebut disampaikan untuk membuat masyarakat bangga dan merasa tidak sungkan untuk menyampaiakan keinginannya dan datang kembali lagi ke kantor tersebut di lain 
kesempatan

apabila

memerlukan lagi informasi yang dibutuhkan.

5. Fungsi tindak tutur secara aserif untuk mengeluh. Tuturan tersebut disampaikan pada saat masyarakat tidak mentaati aturan dalam melakukan antrian dengan baik jika ingin dilayani dengan baik. Juga disampaikan oleh pegawai kepada masyarakat yang tetap minta dilayani pada hal waktu untuk istirahat dalam melakukan pelayanan karena pegawai harus sholat dan makan siang.

6. Fungsi tindak tutur secara aserif untuk menuntut. Tuturan tersebut disampaikan untuk membuat masyarakat datang kembali kekantor tersebut karena urusannya tidak bisa diselesaiakan dihari yang sama. Tindak tutur ini juga digunakan oleh pegawai untuk mengingatkan kepada masyarakat untuk dapat berperan secara aktif memantau perkembangan informasi yang diperlukan oleh masyarakat sendiri. Juga untuk datang sesuai dengan waktu dan hari yang disebutkan oleh pegawai tersebut.

7. Fungsi tindak tutur secara aserif untuk melaporkan. Tuturan tersebut digunakan oleh pegawai ketika menyampaikan informasi yang diperlukan oleh masyarakat yang datang beberapa hari sebelumnya, sehingga diketahui tentang apa yang diharapkan dari informasi yang diberikan oleh pegawai yang melayaninya.

2) Startegi Kesantunan Tindak Tutur Asertif dikalangan Pegawai di Kantor Daerah Kabupaten Bima dalam Memberikan Pelayanan Prima

Berdasarkan penelitian yang dilakukan oleh peneliti dapat ditemukan adanya strategi kesantunan tindak tutur secara asertif yang dilakukan oleh pegawai di lingkungan kantor pegawai daerah kabupaten Bima ada 7 stategi kesantunan yaitu 1) menunjukan keramah tamahan (strategi positif), 2) memperlancar penyampain informasi (strategi positif), 3) memberikan kepastian (strategi positif), 4) menunjukkan keoptimisan (strategi positif), 5) menyatakan tindakan pengancaman 
muka sebagai aturan yang bersifat umum (strategi negatif), 6) memberikan tawaran atau janji (strategi positif), dan 7) memberikan penghargaan (stategi positif).

\section{SIMPULAN}

Simpulan dari penelitian ini bahwa pemakain kesantunan tindak tutur secara asertif dikalangan pegawai dilingkungan kantor daerah kabupaten Bima dalam melakukan pelayanan prima yaitu dapat diklasifikasikan menjadi 7 fungsi tindak tutur secara asertif yaitu 1) Fungsi tindak tutur secara asertif untuk menyatakan, 2) Fingsi tindak tutur secara aserif untuk memberitahukan, 3) Fungsi tindak tutur secara aserif untuk menyarankan, 4) Fungsi tindak tutur secara aserif untuk membanggakan, 5) Fungsi tindak tutur secara aserif untuk mengeluh, 6) Fungsi tindak tutur secara aserif untuk menuntut, 7) Fungsi tindak tutur secara aserrif untuk melaporka. Adapun stategi yang digunakan adalah sebagai berikut; 1) stategi positif meliputi, menunjukan keramah tamahan, memperlancar penyampain informasi, memberikan kepastian, menunjukkan keoptimisan, memberikan tawaran atau janji, dan memberikan penghargaan. 2) strategi negative yaitu menyatakan tindakan pengancaman muka sebagai aturan yang bersifat umum.

\section{DAFTAR PUSTAKA}

Alwasilah, C. 1993. Sosiologi Bahasa. Bandung: Angkasa.

Arikunto, S. 1992. Metode Penelitian suatu Pendekatan Praktik. Surabaya: Usaha Nasional.

Azwar, S. 2014. Metode Penelitian. Yogyakarta: Pustaka Pelajar.

Emzir. 2010. Metodologi Penelitian Pendidikan Kuantitatif dan Kualitatif. Jakarta: Rajawali Press.

Ibrahim, S. 1990. Sosiolinguistik Sajian, Tujuan, Pendekatan dan Problem. Malang: Usaha Nasional.

Leech, G. 1993. Prinsip-Prinsip Pragmatik. Jakarta: UI Press.

Levinson, S.C. 1985. Pragmatis. Australia: Cambridge University Press.

Mardalis. 2008. Metode Penelitian Suatu Pendekatan Proposal. Jakarta: Bumi Aksara.

Margono, S. 2005. Metodelogi Penelitian. Jakarta Rineka Cipta.

Muhammad. 2011. Paradigma Kualitatif Penelitian Bahasa. Yogyakarta : Liebe Book Press.

Pranowo. 2012. Berbahasa Secara Santun. Yogyakarta:Pustaka Pelajar.

Prayitno, J. H. 2011. Kesantunan Sosiopragmatik Studi Pemakaian Tindak Direktif di kalangan Andik SD Berbudaya Jawa. Surakarta: UMM Press. 
Rahardi, K. 2005. Pragmatik Kesantunan Imperatif Bahasa Indonesia. Jakarta: Erlangga

Rahardjo, M. 2002. Pengantar Penelitian Bahasa. Malang: Cendekia Paramulya.

Rusminto, N.E. 2010. Memahami Bahasa Anak-Anak: Sebuah Kajian Analisis wacana. Bandarlampung: Uneversitas Lampung. Tidak Diterbitkan

Searle, J.R. 1997. Speechn Acts. Austalia: Cambridge Universitas Press.

Sedarmayanti dan Hidayat. 2002.

Metodologi Penelitian. Bandung: Mandar Maju.

Sumarsono. 2007. Sosiolinguitik.

Yogyakatra: Pustaka Pelajar.

Sumarsono. 2010. Pragmatik: Buku Ajar.

Singaraja: Universitas Pendidikan Ganesa.

Suryabrata, S. 2013. Metodologi Penelitian. Jakarta: Karisma Utama Putra Offset.

Tarigan, H.G. 2009. Pengajaran Pragmatik. Bandung: Angkasa Bandung.

Tarigan, H.G. 2009. Pengajaran Wacana. Bandung: Angkasa Bandung.

Wijana, I Dewa Putu. 1996. Dasar-dasar Pragmatik. Jakarta: Andi.

Wijana, I Dewa Putu dan Muhammad Rohmadi.2011. Analisis Wacana Pragmatik: Kajian Teori dan Analisis. Surakarta: Yuma Pustaka. 